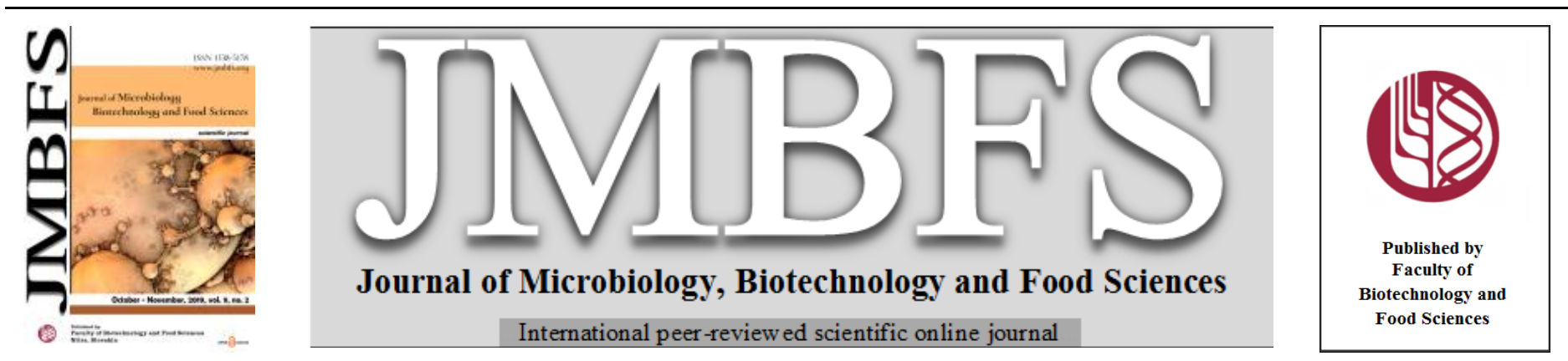

\title{
APPLICATION OF SURFACE RESPONSE METHODOLOGY FOR AN ENZYME-ASSISTED EXTRACTION OF CAROTENOIDS
}

\author{
Parise Adadi ${ }^{*, 1,2,+}$, Nadezhda Vasilyevna Barakova ${ }^{1}$ \\ Address(es): \\ ${ }^{1}$ ITMO University, Faculty of Food Biotechnologies and Engineering, Department of Food Biotechnology for Plant Origin Products, Lomonosova Street 9, St. \\ Petersburg, 191002, Russian Federation. \\ ${ }_{2}^{2}$ ITMO University, International Laboratory "Solution Chemistry of Advanced Materials and Technologies (SCAMT)", Lomonosova Street 9, St. Petersburg, 191002, \\ Russian Federation.
}

${ }^{\ddagger}$ Present address: Department of Food Science, University of Otago, P.O. Box 56, Dunedin 9054, New Zealand.

*Corresponding author: pariseadadi@gmail.com; adadi_parise@scamt-itmo.ru

doi: 10.15414/jmbfs.2019.9.2.195-203

\section{ARTICLE INFO}

Received 20.9. 2018

Revised 25. 3. 2019

Accepted 25. 3. 2019

Published 1. 10. 2019

Regular article open $\partial_{\text {ACCESS }}$

\section{ABSTRACT}

The primary sources of carotenoids are plants and microorganisms (yeast, bacteria), though they can be synthesized chemically. Due to their potent antioxidant properties, carotenoids exert a significant role at the molecular level in the suppression of various cancers and other oncological diseases. The present research aimed to optimize the enzyme-assisted extraction of carotenoids from carrot by response surface methodology. The Box-Behnken design was used for the optimization of extraction conditions from fresh carrot. The response (yield) was quantified using a spectrophotometric method. The highest yield from the experimental result was $393.4 \mu \mathrm{g} / \mathrm{mL}$ followed by $335.4 \mu \mathrm{g} / \mathrm{mL}$ whereas $198.0 \mu \mathrm{g} / \mathrm{mL}$ represents the least. The predicted highest yield $(407.4 \mu \mathrm{g} / \mathrm{mL})$ was more than the experimental yield $(393.4 \mu \mathrm{g} / \mathrm{mL})$. The model was significant $(p=0.0261)$. However, the lack of fit for the ANOVA was not significant $(p=0.3534)$

Keywords: $\beta$-carotene, saponification, DPPH, Fructozym ${ }^{\circledR}$ MA, dicaffeoylquinic acid, chlorogenic acid

\section{INTRODUCTION}

Ever since man has abandoned hunting and gathering, he has learned how to domesticate and cultivate produce (plant and animals), including utilization of what nature has provided (trees, shrubs, etc.), and the human has also mastered how to extract phytochemicals for his health benefits. Numerous phytochemicals have since been extracted for various use among them are lipid-soluble tetraterpenoids commonly known as carotenoids.

Carotenoids are tetraterpenoid pigments, synthesized in all photosynthetic organisms (plants, algae, etc.) and some non-photosynthetic bacteria, yeasts, and molds (Dufosse et al., 2005; Cazzonelli, 2011; Mata-Gómez et al., 2014) These pigments are responsible for hues in flowers, fruits, leaves, fishes (salmon) and in some insects, crustaceans, and birds (flamingos) (Pfander, 1992).

Carotenoids play a significant role at the molecular level of life in the suppression of various cancers (lung, head, neck, and prostate) cells due to their known potent antioxidant properties. The also aid modulation of the immune system, growth factors and intracellular signaling pathways to prevent various ailment. Carotenoids regulate vital cell activities such as cell differentiation, cell cycle, and apoptosis. Furthermore, they help in photoprotection of the skin against UV radiation and serving as precursors for the visual pigment retinol (Vitamin A) (Sain et al., 2015; Singh et al., 2015; Saini and Keum, 2018). Carotenoids are more easily extracted from plant matrices than from microorganisms due to cost and challenging barriers (Bioreactor conditions, cross contaminations, etc.) one has to skip over before getting microorganism to produce them. Moreover, the complex media requirement also makes extracting carotenoids from microorganism not attractive. The most common plant material from which carotenoid can be extracted is a carrot. Fruits and vegetables are the primary sources of carotenoids (Adadi et al., 2018a).

According to FAOSTAT (2013) and Janve et al. (2014) carrot (Daucus carota L.) serve as a carotenoid-rich vegetable from the family Umbelliferae (now known as Apiaceae), order Apiales, class Magnoliosida and kingdom pleantea with China, Russia, USA, and Uzbekistan being the major producers. The moisture, protein, fat, carbohydrate, total sugar, and crude fiber contents of carrot are $84-88.8 \%, 0.7-0.9 \%, 0.2-0.5 \%, 6-10.6 \%, 5.6 \%$, and $1.2-2.4 \%$, respectively. Whereas calcium $0.34-0.80 \mathrm{mg} / \mathrm{g}$, iron $0.004-0.02 \mathrm{mg} / \mathrm{g}$, phosphorus $0.25-0.53$ $\mathrm{mg} / \mathrm{g}$, sodium $0.40 \mathrm{mg} / \mathrm{g}$, potassium $2.40 \mathrm{mg} / \mathrm{g}$, magnesium $0.09 \mathrm{mg} / \mathrm{g}$, copper
$0.0002 \mathrm{mg} / \mathrm{g}$, and zinc $0.002 \mathrm{mg} / \mathrm{g}$ are the minerals in carrot (Kotecha et al., 1998). The variety, the geographical site of production, harvesting, and postharvest handling of carrot tend to alter the content of carotenoids, and this was extensively studied by Heinonen (1990).

Currently, most extractions are solvent based thus utilizing different combinations of solvents (polar and non-polar solvents) to recover high-valued compounds (carotenoids). This sort of discourse has a negative impact on the environment and the health of the consumer (Adadi et al., 2018a).

Therefore, research institutions are tasked to develop a greener approach which either uses less solvent or no solvent at all. However, the high cost of healthcare is another reason to find an alternate approach to extracting valuable compounds without contamination with solvents (Adadi et al., 2018a) which might end up compromising the immune system of the consumer.

Enzyme-assisted extraction (EAE) is the best candidate in curbing the menace mentioned above, but due to high-cost of industrial enzymes collections, the problem remains hanging. Screening of crude enzymes from plant and other microorganisms could be the way forward in solving these problems.

According to Myers et al. (2016), response surface methodology (RSM) is a collection of statistical and mathematical approaches useful for improving, developing, and optimizing processes in the field of sciences, i.e., food science, chemical engineering, industrial and pharmaceutical biotechnology, etc.

Therefore, the present study aims to optimize conditions for high yield of carotenoids using Fructozym ${ }^{\circledR}$ MA and to assess the antioxidant activity (AOA) of the extracts.

\section{MATERIAL AND METHODS}

\section{Sample and reagents}

Carrots were purchased from a local grocery store in St Petersburg, Russia Commercial Fructozym ${ }^{\circledR}$ MA (MA) was obtained from Erbslöh Geisenheim, Germany, whereas ethanol, sodium bicarbonate $\left(\mathrm{NaHCO}_{3}\right)$, and $\beta$ carotene standard were taken from Sigma-Aldrich, USA.

MA is a liquid highly concentrated pectolytic enzyme preparation produced by Aspergillus niger for the destruction of pectic substances during the enzymatic treatment. Due to its specific enzyme composition, MA hydrolyzes primary 
viscous substances of the juicing phase. This helps to quickly squeeze the juice, without destroying the structure of the pulp. The dosage of the enzyme preparation depends on the type of raw material, the degree of ripeness of the fruit, temperature and reaction time. The main activities of the enzyme as indicated by the manufacturer was depicted in Table 1 .

Table 1 The characteristics of enzyme preparation

\begin{tabular}{|c|c|c|c|c|c|c|}
\hline Name & $\begin{array}{c}\alpha \text {-amylase, } \\
\text { EGU g }^{-1}\end{array}$ & $\begin{array}{c}\text { Exo- } \beta \\
\text { glucanases, } \\
\text { EGU g }^{-1}\end{array}$ & $\begin{array}{c}\text { pectinases, } \\
\text { EGU g }^{-1}\end{array}$ & $\begin{array}{c}\text { Endo- } \\
\text { polygalactur } \\
\text { onase, } \\
\text { EGU g }^{-1}\end{array}$ & $\begin{array}{c}\text { Xylanases, } \\
\text { EGU g-1 }\end{array}$ & $\begin{array}{c}\text { Cellulase, } \\
\text { EGU g }^{-1}\end{array}$ \\
\hline Fructozym $® \mathrm{MA}$ & 4 & 42 & 14 & 212 & 11 & 88 \\
\hline
\end{tabular}

EGU=endoglucanase units

The carrot was skinned and cleaned under running tap water with a sponge before blending with Waring Blender. $100 \mathrm{~g}$ carrot paste (puree) was measured into a beaker. Enzyme was accurately measured (Table 2) into each flasks. To ensure efficient enzymatic hydrolysis, $100 \mathrm{~mL}$ of distilled water was added to increase the surface area. The $\mathrm{pH}$ was adjusted using dissolved $\mathrm{NaHCO}_{3}$. A filter bed was prepared on a porcelain Buchner funnel by placing two different \#1 Whatman filter paper, after the incubation period of an enzymatic reaction. This process was done to ensure efficient filtration process. The mixture was then vacuum filtered using a vacuum pump at 2 amps. The first filtrate represents watersoluble pigments and was discarded. Buchner funnel with filter beds containing carotenoids was repeatedly washed with $200 \mathrm{~mL}$ of $95 \%$ ethanol until it turns grey.

\section{Experimental design}

The effects of enzyme dose, $\mathrm{pH}$, temperature, and time on the extraction yield of carotenoids were evaluated using the response surface methodology with the Box-Behnken design. The actual and coded levels of the variables used in the design are depicted in Table 2 . The independent variables were enzyme dose (A, $\mathrm{mL}), \mathrm{pH}(\mathrm{B})$, temperature $\left(\mathrm{C},{ }^{\circ} \mathrm{C}\right)$, and time $(\mathrm{D}, \mathrm{Hrs})$ whereas yield of carotenoids (Y) (Table 3) was defined as the dependent variable in the present experiment Five replicates at the center of the design were used to allow for estimation of a pure error sum of squares.

Table 2 Independent factors and coded levels

\begin{tabular}{ccccc}
\hline & & \multicolumn{3}{c}{ Variable levels } \\
\cline { 3 - 5 } $\begin{array}{c}\text { Independent } \\
\text { variable }\end{array}$ & Coded symbols & -1 & 0 & +1 \\
\hline Enzyme dose $(\mathrm{mL})$ & $\mathrm{A}$ & 0.3 & 0.45 & 0.6 \\
$\mathrm{pH}$ & $\mathrm{B}$ & 4.6 & 6 & 7.4 \\
Temperature $\left({ }^{\circ} \mathrm{C}\right)$ & $\mathrm{C}$ & 30 & 33.5 & 37 \\
Time $(\mathrm{Hr})$ & $\mathrm{D}$ & 12 & 18 & 24 \\
\hline
\end{tabular}

\section{Spectrophotometric estimation of carotenoids}

Total carotenoid concentrations were quantified spectrophotometrically using the equations proposed by Lichtenthaler and Buschmann (2001). $2 \mathrm{~mL}$ of extracts were measured into disposable polymer cuvettes, and the blank was the ethanol used during extraction. Absorbance was quantified with Agilent Cary $60 \mathrm{UV}-\mathrm{V}$ is spectrophotometer (Agilent, CA, US) at 300 to $700 \mathrm{~nm}$. $\beta$-carotene was used as the standard.

\section{Assay of DPPH radical scavenging activity}

DPPH (2, 2-diphenyl-1-picrylhydrazyl) radicals scavenging activity of the carotenoid extract was estimated by the method previously used (Adadi $\boldsymbol{e t}$ al. 2017a) with slight modification. In the present study, carotenoid extracts were used in determining the radical scavenging activity. DPPH $(1 \mathrm{mmol})$ was dissolved in ethanol $(60 \mathrm{~mL})$. The mixture was shaken vigorously and left to stand in the dark at room temperature $\left(28^{\circ} \mathrm{C}\right)$ for 20 minutes and without pretreatment $10 \mu \mathrm{L}$ of the extracts were pipetted into Eppendorf tube containing $\mathrm{mL}$ of DPPH. Electron paramagnetic resonance (EPR Elexys E-500) (Bruker Biospin, Karlsruhe, Germany) spectra of every 30 seconds for 5 minutes were measured. The ability of carotenoid extract to scavenge DPPH radicals was quantified using a formula specified by Ivanova et al. (2017).

\section{Statistical analysis}

All results were averages of duplicate determinations. Design Expert 11 (Tria version (Stat-Ease, MN, USA) was utilized in designing the whole experiment.

\section{RESULTS AND DISCUSSION}

\section{Analysis of the RSM model}

The results of 30 runs using the Box-Behnken design are listed in Table 3 Analysis of variance (ANOVA) and regression was calculated using the experimental results. The coefficients, such as linear, quadratic and interaction, are reported in Table 4.

The model $F$-value of 2.86 implies the model is significant $(p=0.0261)$. There is only $2.61 \%$ chance that an $F$-value this large could occur due to noise. In statistics, noise can be defined as unexplained variations in the experiment or factors that are inevitable to control (Steinberg and Bursztyn, 1998). $P$-values less than 0.0500 indicate model terms are significant. In the present $\mathrm{AC}$ $(p=0.0373), \mathrm{C}^{2}(p=0.0006)$ are significant model terms. Values higher than 0.1000 indicate the model terms are not significant. Since there are many insignificant model terms in this work, the solution would be to improve the model by reducing the parameters (i.e., remove time).

The lack of fit $F$-value of 1.46 implies the lack of fit is not significant relative to the pure error. There is a $35.34 \%$ chance that a lack of fit $F$-value could occur due to noise. Non-significant lack of fit is good because we want the model to fit. As stated by Myers et al. (2016), $\mathrm{R}^{2}$ value is always between 0 and 1 and the closer the $\mathrm{R}^{2}$ is to 1.0 , the stronger the model and the better it predicts the response. The $\mathrm{R}^{2}$ of the current model is 0.73 hence useful in predicting the yield of carotenoid.

The regression models representing the effect of temperature, $\mathrm{pH}$, enzyme dose, and time on carotenoid yield are expressed in equation 1 .

Carotenoid $=261.56+9.02 \mathrm{~A}-5.14 \mathrm{~B}-10.64 \mathrm{C}+9.45 \mathrm{D}+2.04 \mathrm{AB}-$

$21.58 \mathrm{AC}-10.36 \mathrm{AD}-5.60 \mathrm{BC}+15.65 \mathrm{BD}-9.74 \mathrm{CD}-6.72 \mathrm{~A}^{2}-3.49 \mathrm{~B}^{2}+$

$31.13 C^{2}-8.31 D^{2}$

Per the monomial coefficient value of regression model equation (1), $A=9.02$ (incubation temperature), $\mathrm{B}=5.14(\mathrm{pH}), \mathrm{C}=10.64$ (enzyme dose), and $\mathrm{D}=9.45$ (time), the order of priority among the main effects of factors is as follows: enzyme dose (C) > time (D) > incubation temperature (A) $>\mathrm{pH}$ (B).

The adjusted $\mathrm{R}^{2}$ was 0.50 , indicating that the model was reasonably adequate in predicting the variation of the response. However, a negative predicted $\mathrm{R}^{2}(-0.30)$ implies that the overall mean could be a better predictor of the response (yield of carotenoid) than the current model. In some cases, a higher order model may also predict better, but this does not stop us from using the model. The adequacy of prediction measures the signal to noise ratio. A ratio greater than 4 is desirable. In the present study, the ratio was 7.5, which indicates an adequate signal. Therefore, the current model can be used to navigate the design space. 
Table 3 The Box-Behnken design and response for the yield of carotenoid

\begin{tabular}{|c|c|c|c|c|c|c|}
\hline \multirow[t]{2}{*}{ Run } & \multirow[t]{2}{*}{ Temperature $\left({ }^{\circ} \mathrm{C}\right)$} & \multirow[t]{2}{*}{$\mathrm{pH}$} & \multirow[t]{2}{*}{ Enzyme (mL) } & \multirow[t]{2}{*}{ Time (Hrs) } & \multicolumn{2}{|c|}{ Carotenoid yield $(\mu \mathrm{g} / \mathrm{mL})$} \\
\hline & & & & & Actual & Predicted \\
\hline 1 & 30 & 6 & 0.45 & 18 & 254.8 & 216.6 \\
\hline 3 & 33.5 & 6 & 0.45 & 18 & 247.8 & 261.6 \\
\hline 4 & 30 & 4.6 & 0.3 & 12 & 254.8 & 241.9 \\
\hline 6 & 33.5 & 6 & 0.45 & 18 & 247.8 & 261.6 \\
\hline 7 & 33.5 & 6 & 0.45 & 24 & 273.2 & 247.2 \\
\hline 8 & 37 & 6 & 0.45 & 18 & 229.2 & 252.7 \\
\hline 9 & 37 & 4.6 & 0.3 & 12 & 335.431 & 319.7 \\
\hline 10 & 33.5 & 6 & 0.45 & 18 & 307.6 & 261.6 \\
\hline 13 & 33.5 & 6 & 0.45 & 18 & 212.1 & 237.3 \\
\hline 14 & 30 & 7.4 & 0.6 & 12 & 248.5 & 237.6 \\
\hline 15 & 33.5 & 3.2 & 0.45 & 18 & 297.7 & 257.9 \\
\hline 16 & 37 & 4.6 & 0.3 & 24 & 272.9 & 306.1 \\
\hline 17 & 33.5 & 6 & 0.45 & 18 & 281.0 & 261.6 \\
\hline 18 & 37 & 7.4 & 0.6 & 12 & 266.2 & 237.3 \\
\hline 19 & 37 & 4.6 & 0.6 & 12 & 272.1 & 286.0 \\
\hline 20 & 30 & 4.6 & 0.6 & 24 & 256.8 & 283.3 \\
\hline 21 & 30 & 4.6 & 0.6 & 12 & 251.4 & 294.5 \\
\hline 28 & 30 & 7.4 & 0.3 & 12 & 200.0 & 207.4 \\
\hline 29 & 37 & 7.4 & 0.6 & 24 & 212.1 & 247.3 \\
\hline 30 & 37 & 4.6 & 0.6 & 24 & 248.5 & 233.4 \\
\hline
\end{tabular}

Table 4 Analysis of variance and regression coefficients of the predicted second-order polynomial model

\begin{tabular}{|c|c|c|c|c|c|c|c|}
\hline Source & Coefficient & Sum of Squares & Df & Mean Square & $F$-value & $p$-value & Remarks \\
\hline Model & 261.56 & 57163.62 & 14 & 4083.12 & 2.86 & 0.0261 & Significant \\
\hline A-Temp & 9.02 & 1952.74 & 1 & 1952.74 & 1.37 & 0.2604 & \\
\hline B-pH & -5.14 & 634.84 & 1 & 634.84 & 0.44 & 0.5150 & \\
\hline C-Enzyme & -10.64 & 2714.81 & 1 & 2714.81 & 1.90 & 0.1881 & \\
\hline D-Time & 9.45 & 2141.56 & 1 & 2141.56 & 1.50 & 0.2395 & \\
\hline $\mathrm{AB}$ & 2.04 & 66.60 & 1 & 66.60 & 0.05 & 0.8319 & \\
\hline $\mathrm{AC}$ & -21.58 & 7451.42 & 1 & 7451.42 & 5.22 & 0.0373 & \\
\hline $\mathrm{AD}$ & -10.36 & 1716.02 & 1 & 1716.02 & 1.20 & 0.2902 & \\
\hline $\mathrm{BC}$ & -5.60 & 501.58 & 1 & 501.58 & 0.35 & 0.5622 & \\
\hline $\mathrm{BD}$ & 15.64 & 3916.09 & 1 & 3916.09 & 2.74 & 0.1184 & \\
\hline $\mathrm{CD}$ & -9.74 & 1519.41 & 1 & 1519.41 & 1.06 & 0.3185 & \\
\hline $\mathrm{A}^{2}$ & -6.72 & 1239.50 & 1 & 1239.50 & 0.87 & 0.3662 & \\
\hline$B^{2}$ & -3.49 & 333.50 & 1 & 333.50 & 0.23 & 0.6358 & \\
\hline $\mathrm{C}^{2}$ & 31.13 & 26583.91 & 1 & 26583.91 & 18.62 & 0.0006 & \\
\hline $\mathrm{D}^{2}$ & -8.31 & 1892.69 & 1 & 1892.69 & 1.33 & 0.2675 & \\
\hline Residual & & 21410.82 & 15 & 1427.39 & & & \\
\hline Lack of Fit & & 15957.53 & 10 & 1595.75 & 1.46 & 0.3534 & not significant \\
\hline Pure Error & & 5453.29 & 5 & 1090.66 & & & \\
\hline Cor Total & & 78574.44 & 29 & & & & \\
\hline R-Square & 0.7275 & & & & & & \\
\hline Adjusted R-Square & 0.4732 & & & & & & \\
\hline Predicted R-Square & -0.2697 & & & & & & \\
\hline Adequate precision & 7.4836 & & & & & & \\
\hline
\end{tabular}




\section{Surface response analysis}

The response surface plots of the carotenoid yield as a function of the different independent variables are presented in Fig. 1. Three-dimensional (3D) plots were obtained by keeping the variable constant at the center point while changing the independent variables within the experimental results.

The yield of the actual and predicted values are presented in Table 3 . The highest yield from the experimental result was $393.4 \mu \mathrm{g} / \mathrm{mL}$ followed by $335.4 \mu \mathrm{g} / \mathrm{mL}$ whereas $198.0 \mu \mathrm{g} / \mathrm{mL}$ represents the least. The predicted highest yield (407.4 $\mu \mathrm{g} / \mathrm{mL})$ was more than the experimental yield $(393.4 \mu \mathrm{g} / \mathrm{mL})$, and this could be explained using the model. The model considered in the present study was significant ( $p=0.0261)$ hence the predicted results are true and should be included in the results.

It can be seen in the plots (Figure $1 \mathrm{a}, \mathrm{a} 1$ ) that, there was an increase in the carotenoid yield with a decrease in enzyme dose, with the highest yield in the enzyme dose ranged between 0.3 to $0.4 \mathrm{~mL}$. Beyond this value range, the yield decreased with the increase of the enzyme. Similarly, figure $1 \mathrm{~b}, \mathrm{~b} 1$ shows the interaction effect of the enzyme and $\mathrm{pH}$ value on the yield. As shown on the contour plots, decrease in enzyme dose (between $0.37-0.54 \mathrm{~mL}$ ) led to an increase in yield at $\mathrm{pH}$ of 4.0 to 6.7. The efficiency of extraction depends on many factors, among them are; appropriate enzymes (Pectinase, cellulase, Fructozym ${ }^{\circledR} \mathrm{MA}$ ), optimum operating conditions (temperature, $\mathrm{pH}$, etc.), and the substrate (plant matrices).

According to Thaipong et al. (2005) enzyme complex can help enhance the extractability of pigments from a plant by destroying the cell wall (structura integrity) of the material. Moreover, the cell wall of the sample (carrot) is known to be composed of cellulose, lignin, pectin, hemicellulose which serve as sacs for the pigments (Lineback, 1999). These sacs are liberated by the enzyme (MA) hydrolysis, thereby creating pores through which the pigments are leaked into extracting solvents for harvesting.

Çinar (2005) and Sadighara et al. (2016) applied cellulase, pectinase, and trypsin respectively, during extraction of carotenoids from various plant matrices. In both cases, there was a significant increase in yield, due to the activities of the proteins. Enzymes not only optimize the yield but also provide products (carotenoid) which are accepted by consumers. Babu et al. (2008) also utilized trypsin to recover the highest carotenoid contents from shrimp wastes.

MA hydrolyzes the cell wall, liberating carotenoids, thus increases extraction index. Blending of carrot before subjecting enzyme hydrolysis could attribute to chlorophylls detected (results were not included). Chlorophylls are inevitable because they contribute to plant survival via photosynthesis. Enzyme indeed played a critical role in optimizing yield as the interaction regression of temperature and enzyme (AC) was significant $(p<0.05)$

Figure $1 \mathrm{c}, \mathrm{c} 1$ represents the interaction effects of the time and temperature on the yield. For a time value below 15 hours, the yield decreased. The contour plots indicate that the optimum region for the better yield was in the time range of 14 24 and the temperature of 34.4 to $37^{\circ} \mathrm{C}$.

Nevertheless, figure $1 \mathrm{~d}, \mathrm{~d} 1$, shows the interaction effects of the time and $\mathrm{pH}$ value on the carotenoid yield. As seen on the contour plot, the increase in time and $\mathrm{pH}$ led to an increase in yield. Regardless of dosage of the enzyme combinations, the extraction time can be reduced (Cinar, 2005). A similar trend was observed in the present study as the minimum and maximum dose of MA optimized yield. However, this was not true in all the samples. Some of the treatments incubated at different time regime $(12,18 \mathrm{hrs})$ liberated more pigments than treatments of 24 hours. Enzyme quickly utilized all the substrate within the 12 hours of the incubation period, hence there was no further increase in reaction when the time was extended due to lack of substrates. According to Koolman and Roehm (2011), the activity of an enzyme is only possible in the presence of a substrate which must conform to the active site of the enzyme in question before a reaction can occur. However, the lack of or inadequate substrate might explain why the highest yields were detected irrespective of the incubation period. Moreover, enzymes cleave their substrates in a highly specific way, and this phenomenon is not time dependent. Another postulate is that; the shape of the substrate was destroyed after the catalytic activities commenced due to heat or variation in $\mathrm{pH}$ hence no further reaction occurred.

The interaction effects of the temperature and enzyme dose on the yield are presented in figure $1 \mathrm{e}, \mathrm{e} 1$. From the contour plot, increase in temperature led to an increase in yield with a decrease in enzyme dose. The rate of enzymatic reaction increases as temperature increases, but at a certain point $\left(43{ }^{\circ} \mathrm{C}\right)$ except thermophilic enzymes, the reaction starts to decline as the proteins denature (Koolman and Roehm, 2011). Samples were subjected to different temperature regimes. MA was able to act on the carrot cells, thus creating pores for pigments to leak out and this account for better yield in all the samples.

The interaction effects of $\mathrm{pH}$ and temperature on the yield is displayed in figure 1 $\mathrm{f}$, f1. From the plots, there was an increase in yield with an increase in temperature (from 32 to $37^{\circ} \mathrm{C}$ ), with the maximum yield in the $\mathrm{pH}$ range of 4.6 to 6 . Beyond this value range, the yield started to decrease with the decrease of the temperature.

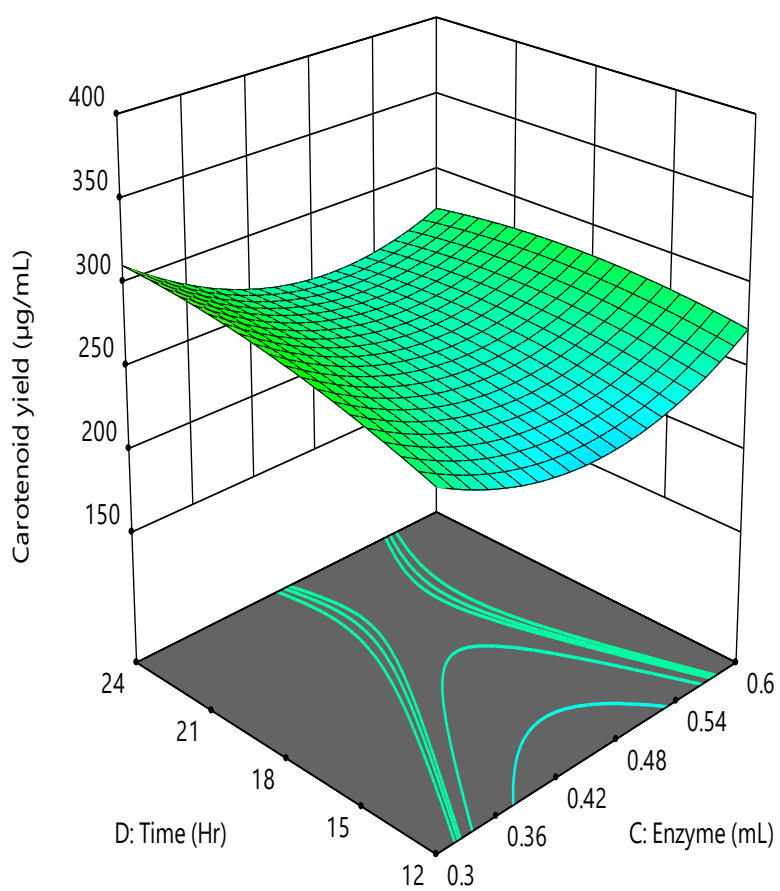

A

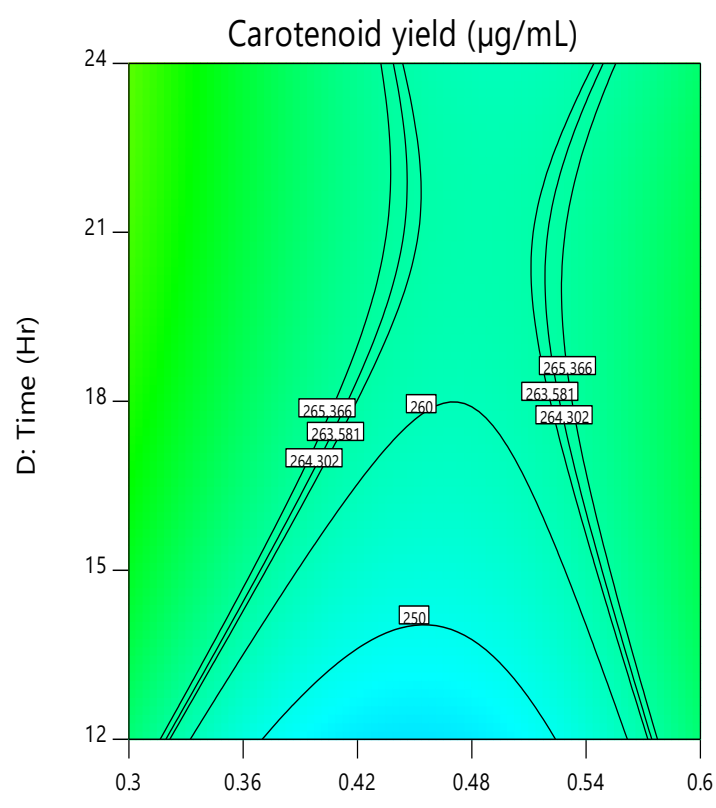

C: Enzyme (mL) 


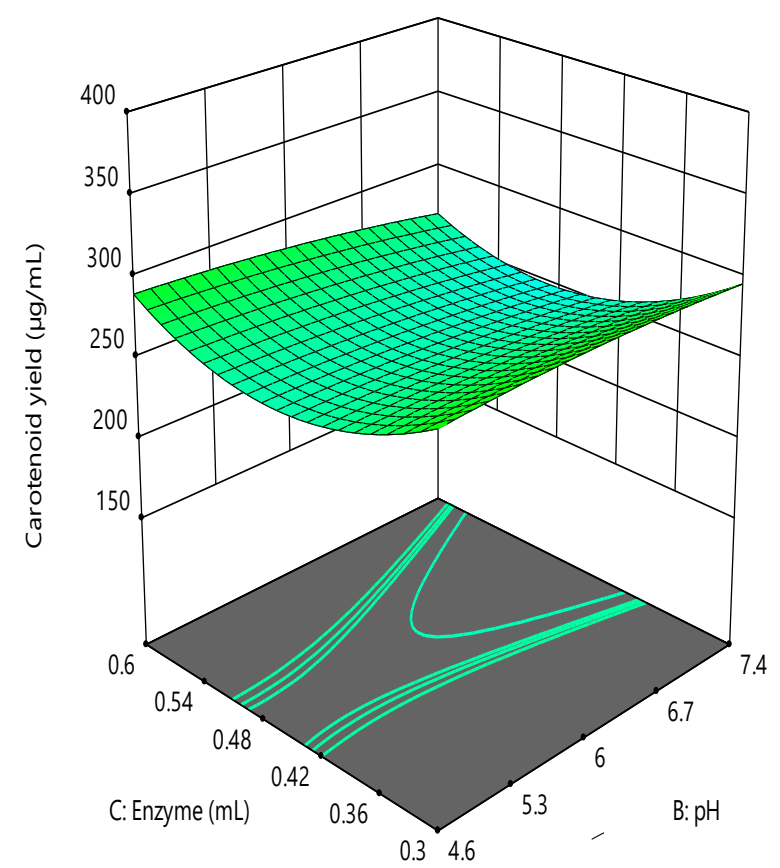

B

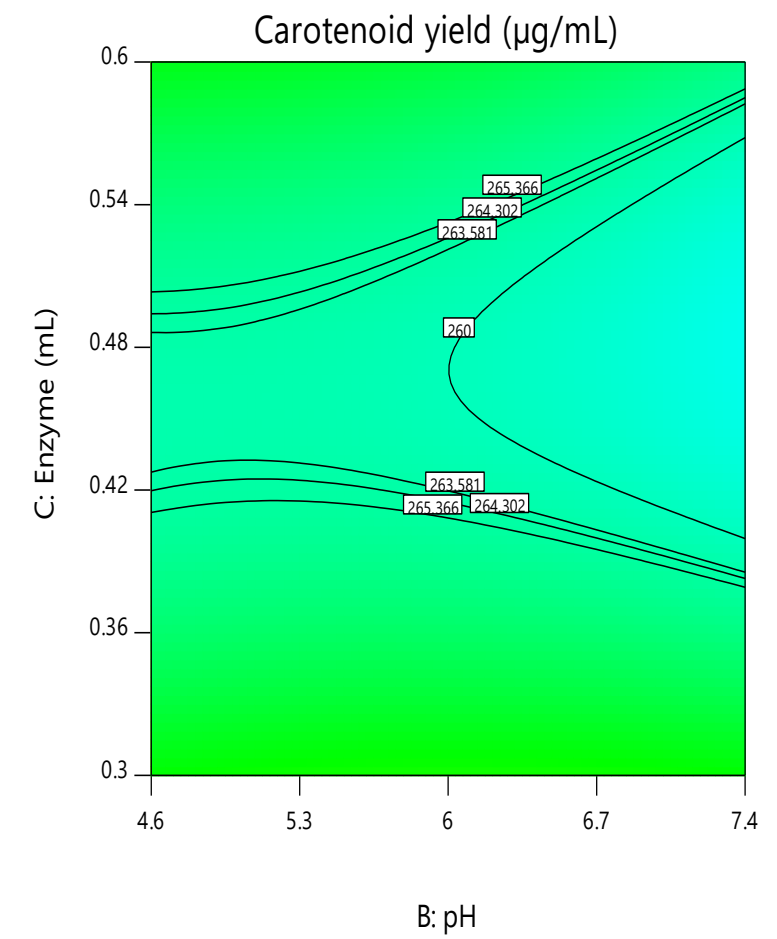

B1

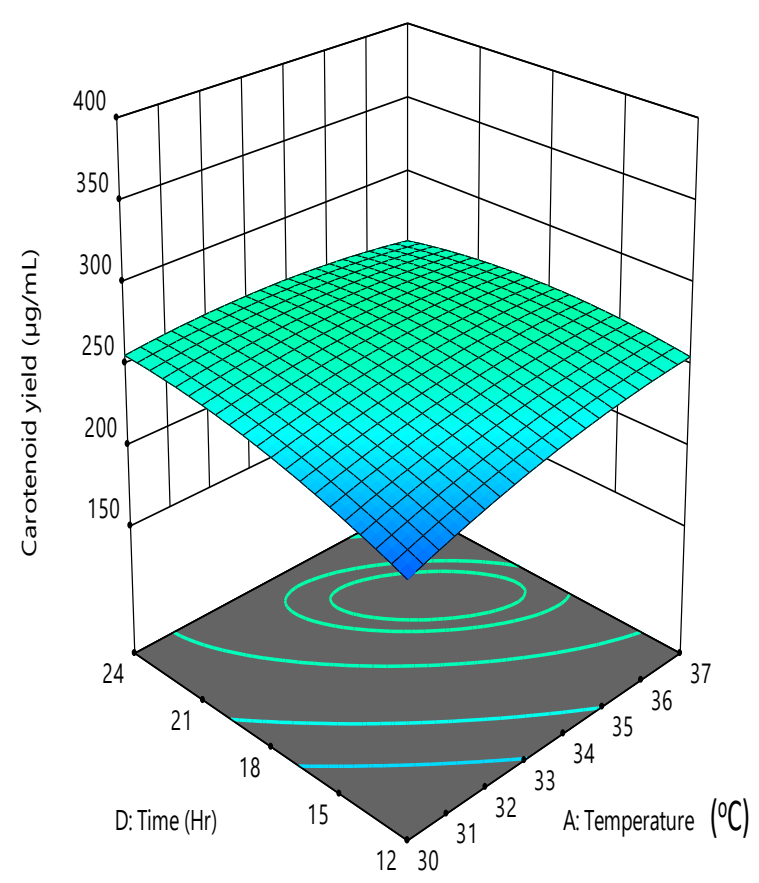

C

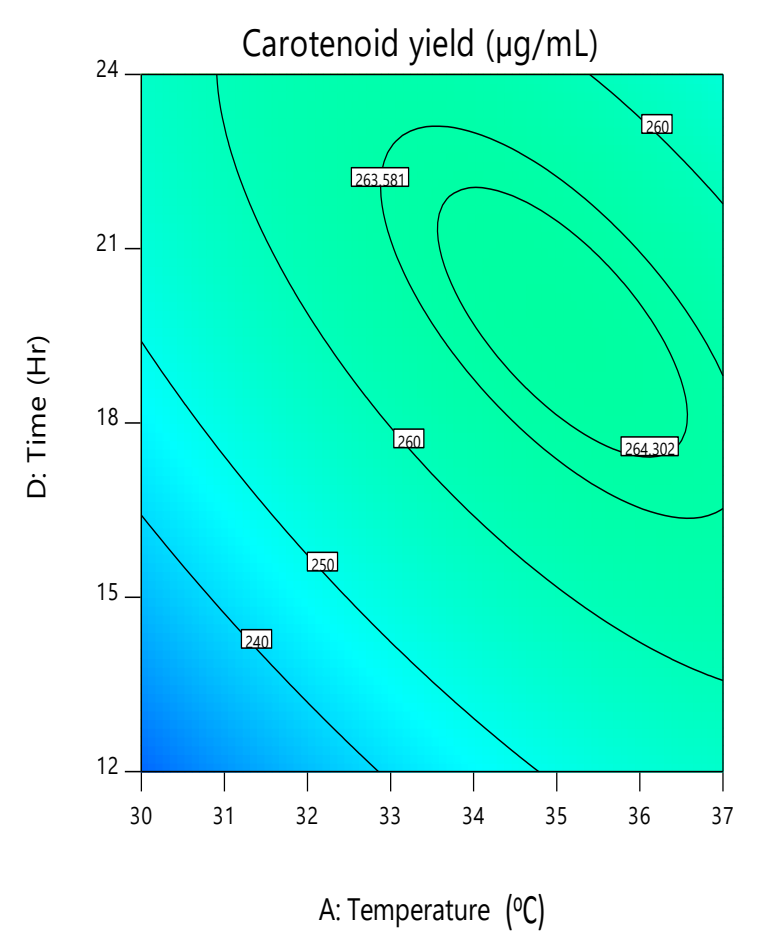

C1 


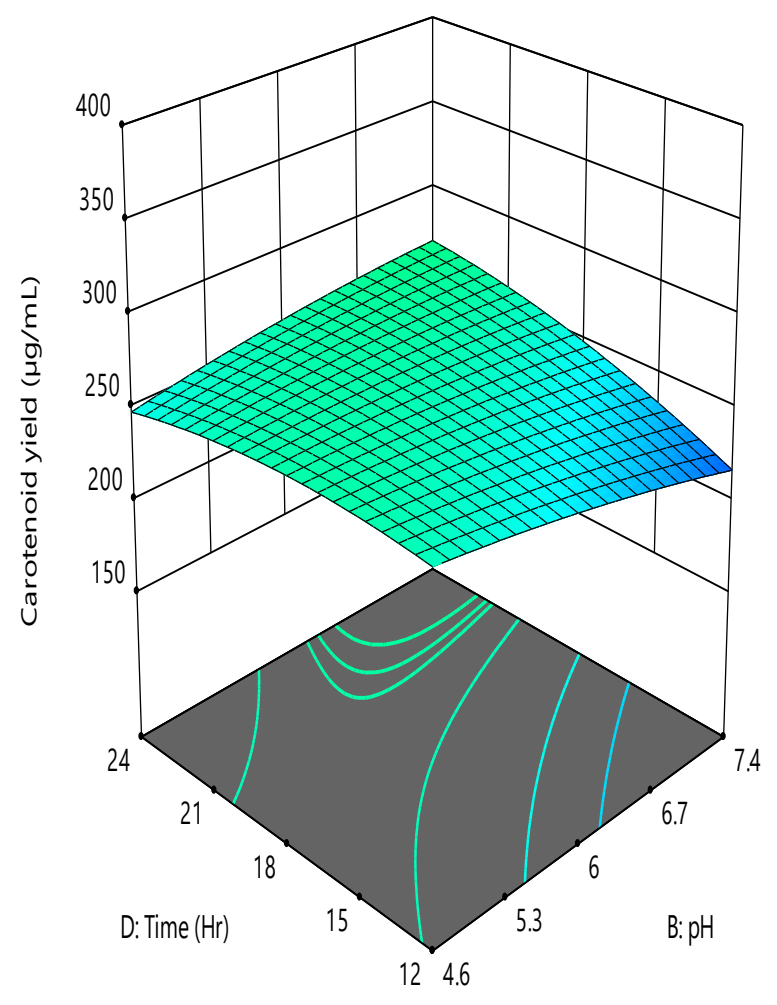

D

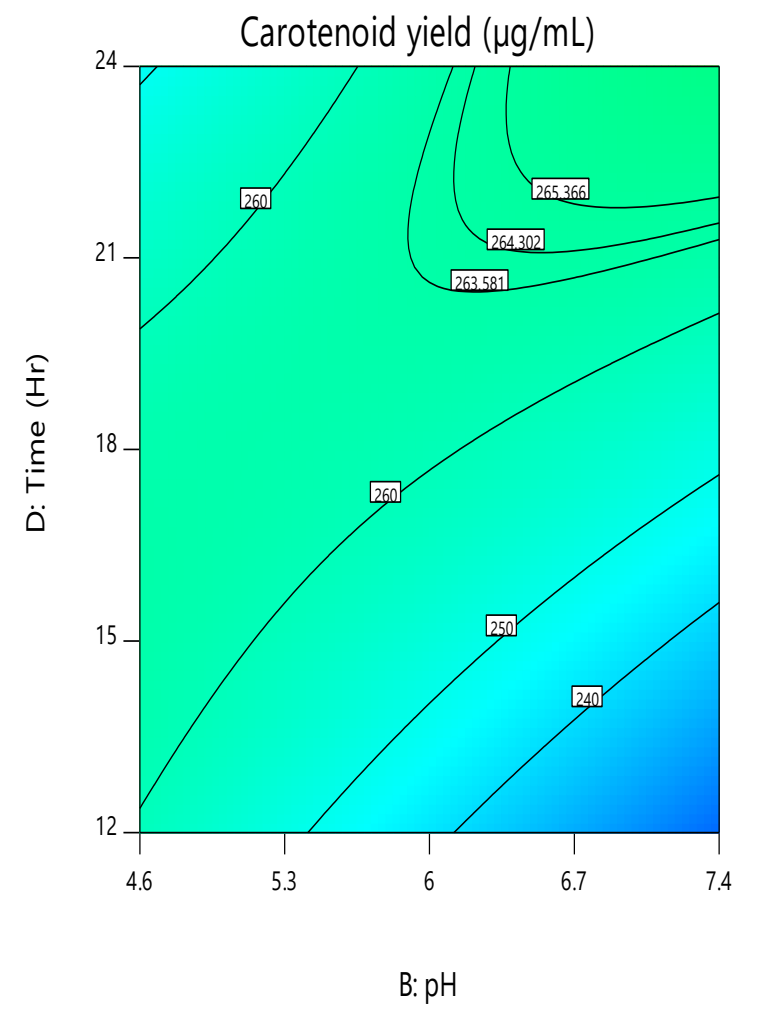

D1

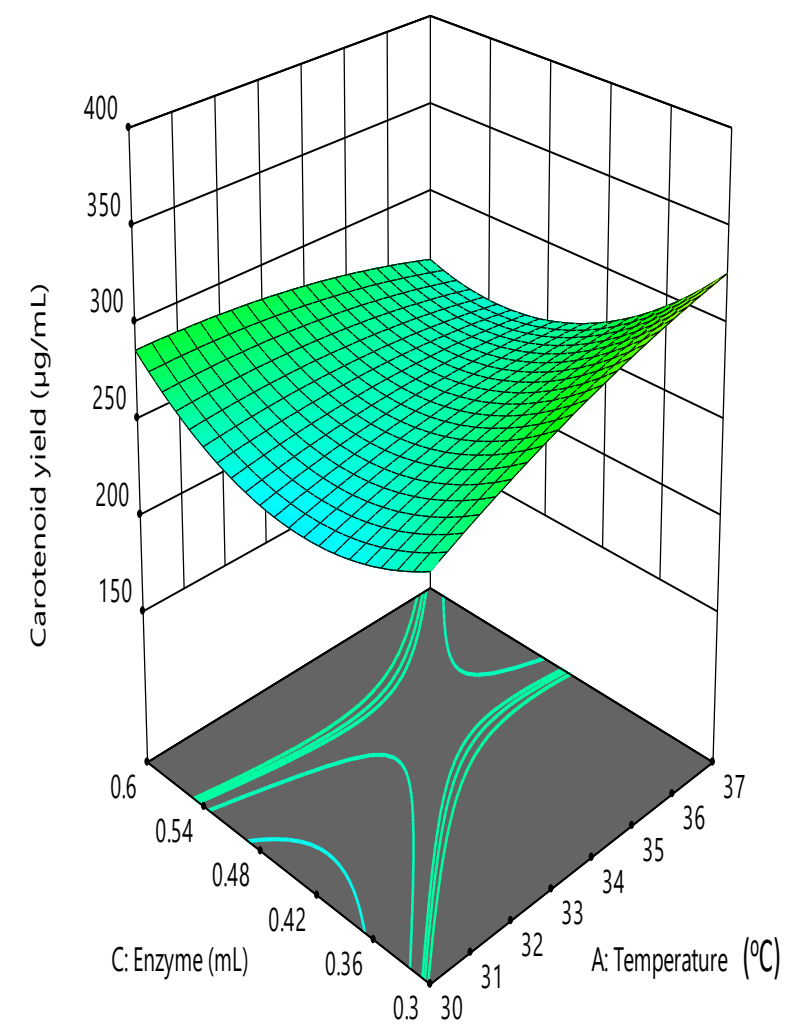

E

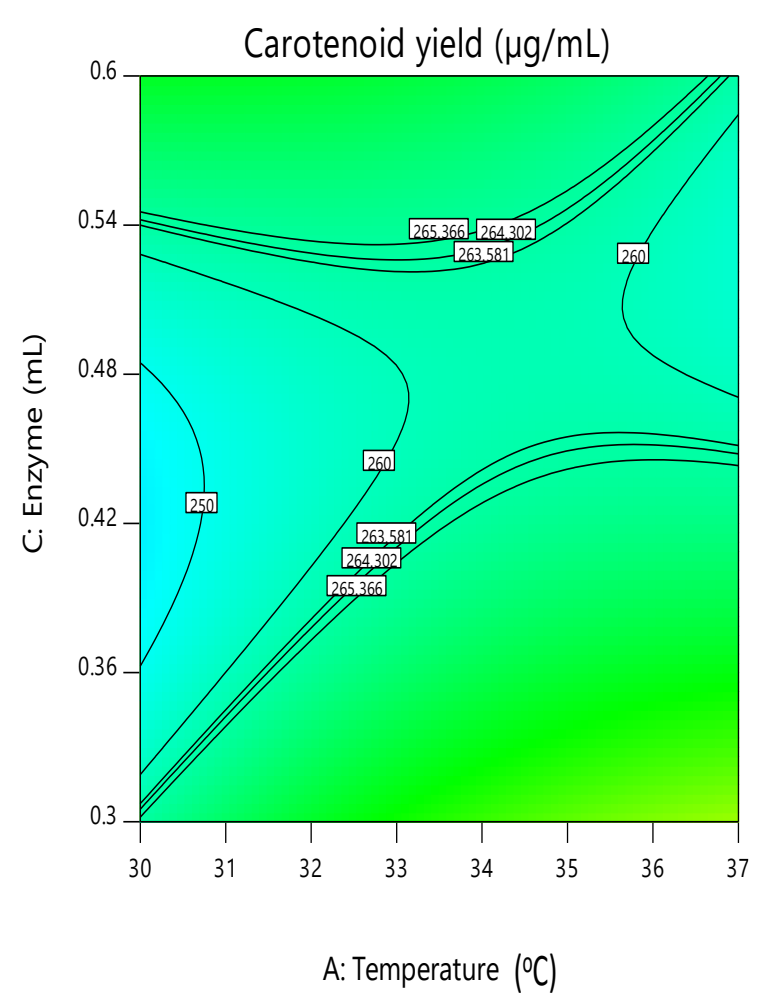

E1 


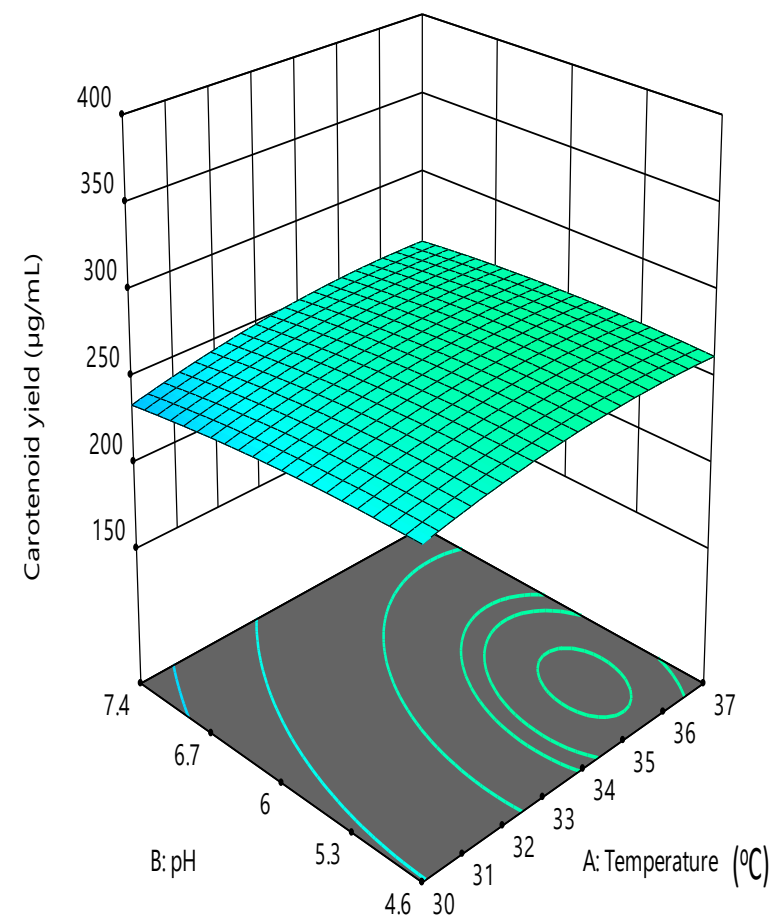

$\mathbf{F}$

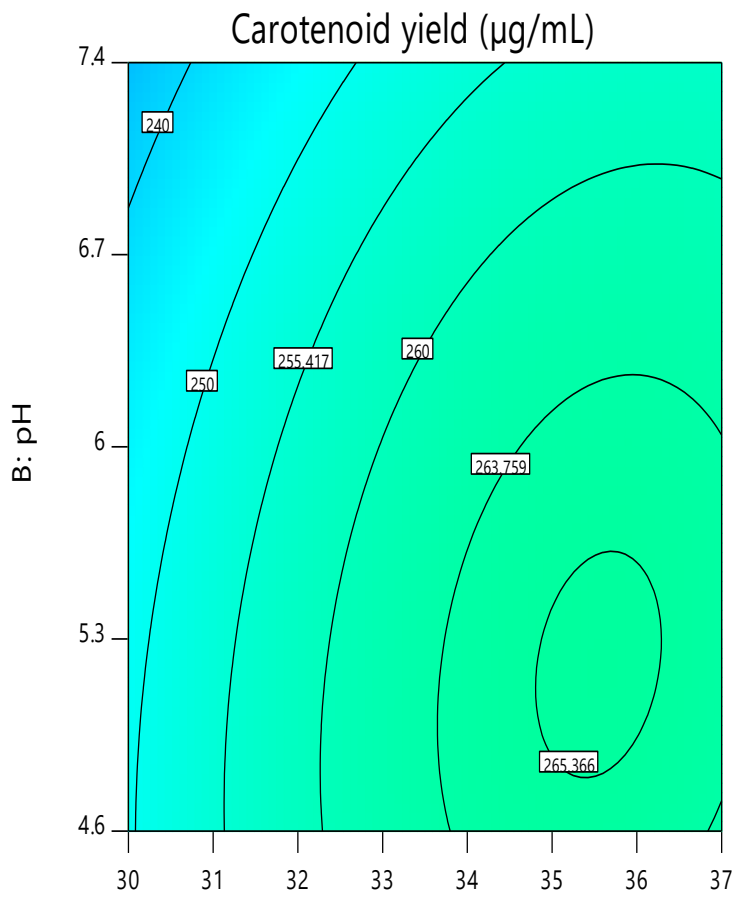

\section{F1}

Figure 13 D response surfaces and contour plots for carotenoid yield as a function of time and enzyme dose (a,a1); enzyme dose and $\mathrm{pH}(\mathrm{b}, \mathrm{b} 1)$; time and temperature $(\mathrm{c}, \mathrm{c} 1)$; time and $\mathrm{pH}(\mathrm{d}, \mathrm{d} 1)$; enzyme dose and temperature (e,e1); $\mathrm{pH}$ and temperature $(\mathrm{f}, \mathrm{f} 1)$.

The catalytic properties of enzymes, and consequently their activity is strongly $\mathrm{pH}$ dependent. A bell-shaped curve is usually obtained when enzyme activities are plotted against $\mathrm{pH}$ value (Sauro, 2011). Addition of water to increase surface area for optimal enzymatic hydrolysis would sharply change the $\mathrm{pH}$ of the carrot paste. This would have affected the activities of MA significantly. Hence, adjusting $\mathrm{pH}$ certainly ensured optimum hydrolysis of MA to yield higher extraction index. Sadighara et al. (2016) also adjusted $\mathrm{pH}$ when they extracted carotenoids from Alfalfa with trypsin, and this led to an increase in yield. From the results, $\mathrm{pH}$ value of 6 was the optimum $\mathrm{pH}$ at which MA hydrolysis was high (taking into consideration the samples with the highest extraction index) though $\mathrm{pH}$ of 7.5, also showed similar results in some of the samples. It is therefore recommended to adjust $\mathrm{pH}$ to 6 when using MA for a higher yield. Figure 2 shows the ramp function graph of desirability for the responses. The dots on each ramp indicate the factor settings or response prediction for that response characteristic. In the current experiment, if all responses were maximized, then optimal parameters for better carotenoid yield were: temperature $\left(37{ }^{\circ} \mathrm{C}\right), \mathrm{pH}$ (7.4), enzyme $(0.3 \mathrm{~mL})$, and time ( $24 \mathrm{hrs}$.). High-cost of industrial enzymes makes it difficult for self-funded researchers to purchase. It is, therefore, a good idea that the desirability function recommended a low enzyme dose with other factors for yield optimization. An alternative option is to entrap MA in alumina gel before use. The entrapped enzyme could be recovered and reused without the enzyme losing its activities. The technology of mechanochemical assisted extraction is another route where carotenoids could be extracted without the need for enzymes. This method could be the best method to extract carotenoids since it operates at low temperature, economical, clean (green method), and thus reduce the impact of solvents on the environment.

\footnotetext{
A: Temperature $\left({ }^{\circ} \mathrm{C}\right)$
} 

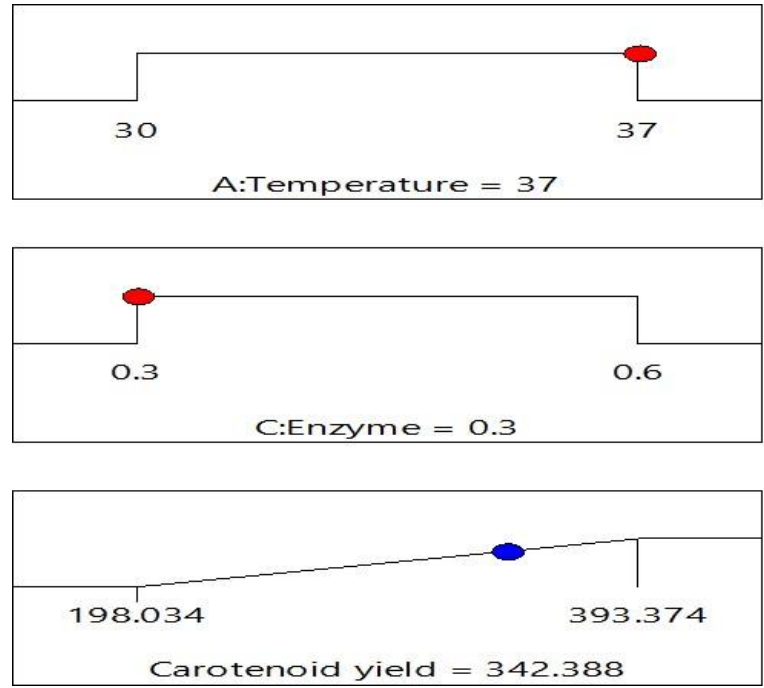
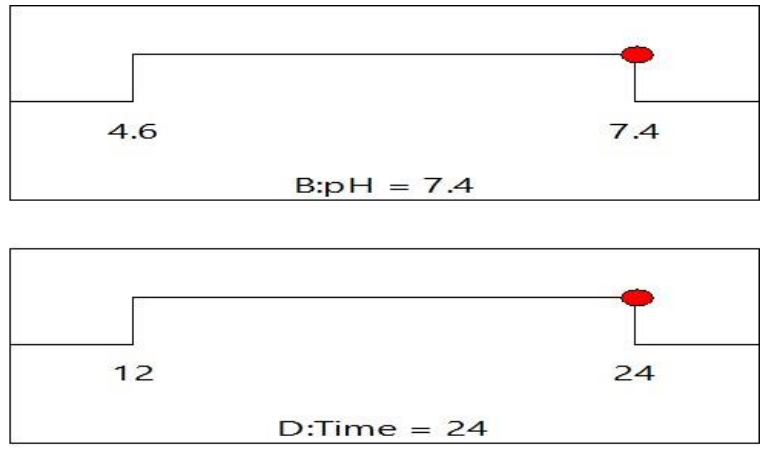

D:Time $=24$

Figure 2 Ramp function graph of desirability

\section{Antioxidant activities}

All the extracts were found to possess DPPH-scavenging activity (Figure 3). Sample 23 exhibited the highest AOA $\left(1.39 \times 10^{-04} \mathrm{~mol} \times\right.$ equ $)$ followed by $1.34 .09 \times 10^{-04}, 1.05 \times 10^{-04}, 1.03 \times 10^{-04}, \mathrm{~mol} \times$ equ representative sample $7,20,18$, respectively. The least $\mathrm{AOA}\left(-1.07 \times 10^{-06} \mathrm{~mol} \times\right.$ equ $)$ was observed in sample 11 . However, sample number 3, 5, 6, 13, 14, 27, 29 and 30 also showed low AOA. In previous studies (Adadi et al., 2017a, 2017b, 2018b) the AOA was measured over 15 minutes, but due to the sample size in the present study, the time was reduced to 5 minutes. Fluctuation in AOA of carotenoid extracts could be attributed to the different treatment regime of the samples.

However, the geographical location, variety of carrot, the farming system adopted could not be ignored as crucial factors that contribute to variation in DPPH scavenging activities.

The plant produce, i.e. fruits and vegetables are the most abundant sources of natural antioxidants, readily available, inexpensive, and more reliable than any expensive artificial medicament, also, it has no side effects and possesses high safety index (Amina et al., 2018). Several authors (Divya et al., 2012; ElZaeddia et al., 2017; Pradeesh and Swapna, 2018) have all confirmed the AOA of extracts from plant matrixes.

Carrot is found to contain hydroxycinnamic derivatives such as dicaffeoylquinic and chlorogenic acids (Zhang and Hamauzu, 2004) and is thought to exert strong antioxidant activities. Extracts of Sesbania grandiflora (L.) were also found to contain potent antioxidant agents responsible for suppressing free radicals in cells. The flowers, when eaten as a vegetable, could serve as a good source of dietary antioxidants, which play an essential role in patience's suffering from diseases associated with oxidative stress (Pradeesh and Swapna, 2018).

Extracts from carrot tissues (peel, phloem, xylem) were found to possess strong DPPH-scavenging activity (Zhang and Hamauzu, 2004). Leja et al. (2013) examined extracts of 35 carrot cultivars, landraces, and breeding populations and established that red carrots possess higher AOA than orange, yellow, and white carrots. Another interesting revelation was that carrots from Asian origin within the Eastern gene pool were more often purple or red and exhibited higher antiradical activity than their counterparts from the Western gene pool with mainly orange roots. Carrots are highly enriched with $\beta$-carotene, and vitamins ( $\mathrm{C}$ and $\mathrm{E})$, which are all candidates for radical scavenging activity. However, among the methods (ferric reducing antioxidant power (FRAP), ABTS bleaching assay ( $\alpha$ TEAC), DPPH assay and peroxyl radical scavenging assay) employed to study the antioxidants activities of juice (from tomato, carrot, sea buckthorn berry) and oils (from sunflower, olive, fish, and walnut), carotenoids did not show any DPPH scavenging activity with the exception $\alpha$-tocopherol, 2-tertbutyl-4-hydroxyanisol (BHA) and 2,6-di-tert-butyl-4-hydroxytoluene (BHT) (Müller et al., 2011). The authors used industrial prepared samples which are usually incorporated with preservatives and could have interfered with the DPPH scavenging activity.

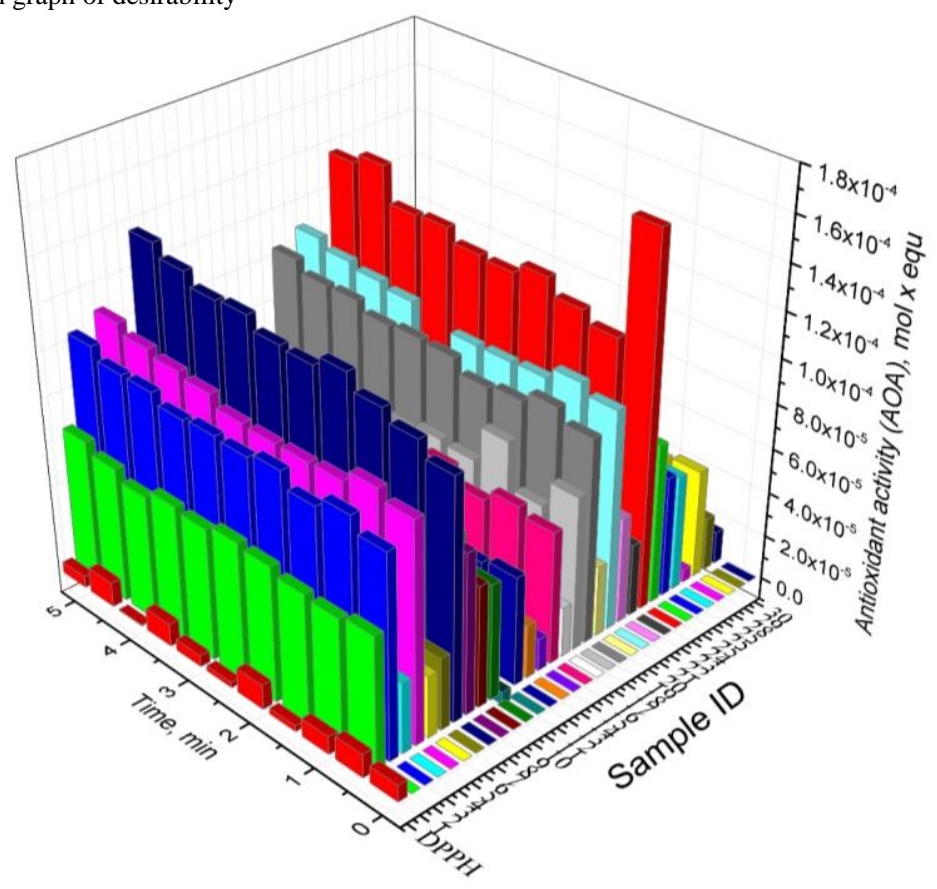

Figure 3 DPPH radical scavenging activity of carotenoid extracts.

\section{CONCLUSION}

In the present study, Box-Behnken design with four factors at three different levels was utilized to evaluate and optimize the EAE of carotenoids from carrots The optimal operating conditions of temperature $\left(37^{\circ} \mathrm{C}\right), \mathrm{pH}(7.4)$, enzyme $(0.3$ $\mathrm{mL}$ ), and time ( $24 \mathrm{hrs}$.) were obtained from the ramp function graph of desirability. EAE is a more effective and efficient method of extracting carotenoids from the plant matrixes. Moreover, this method is economical and poses no threat to the environment as compared to the solvent-assisted extraction. Therefore, the product will be widely accepted by consumers without any criticism. Enzymes (immobilized) utilized could be recovered and re-used since enzymes do not transform into the final products. All the extracts were found to possess DPPH-scavenging activity with $1.39 \times 10^{-04} \mathrm{~mol} \times$ equ and $-1.07 \times 10^{-06}$ mol $\times$ equ representing the highest and least activity respectively. Since carotenoids are liable to heat, light, oxygen, etc., (Adadi et al., 2018a) coupled with the various conditions applied, a piece of information on isomerization of carotenoids would be good, we are, therefore recommending this for future investigations.

Acknowledgments: The authors are grateful to Petrov, A. S., from the Department of Analytical Chemistry, Ural Federal University, Yekaterinburg, Russia for running the Electron paramagnetic resonance (EPR) during the work. The government of the Russian Federation, grant $08-08$, financially supported this work. 


\section{REFERENCES}

Adadi, P., Barakova, V. N., Krivoshapkina, E. F. (2018a). Selected methods of extracting carotenoids, characterization, and health concerns: A review. Journal of Agricultural and Food Chemistry, 66(24), 5925-5947. https://doi.org/10.1021/acs.jafc.8b01407

Adadi, P., Kovaleva, E. G., Glukhareva, T. V., Shatunova, S. A., Petrov, A. S. (2017a). Production and analysis of non-traditional beer supplemented with sea buckthorn. Agronomy Research, 15(5), 1831-1845. https://doi.org/10.15159/AR.17.060

Adadi, P., Kovaleva, E. G., Glukhareva, T. V., Barakova, N. V. (2018b). Production of antioxidant rich beverage: utilizing Monascus purpureus IHEM LY2014-0696 and various malts. Agronomy Research, 16(S2), 1312-1321. https://doi.org/10.15159/AR.18.028

Adadi, P., Kovaleva, E. G., Glukhareva, T. V., Shatunova, S. A. (2017b) Biotechnological production of non-traditional beer. AIP Conference Proceedings, 1886, 020098. http://dx.doi.org/10.1063/1.5002995

Amina, B., Ahmed, T., Hamdi, B., Chawki, B., Salah. R. (2018). Phytochemica constituents, phenolic contents, and antioxidant activity of Crataegus azarolus extracts. Asian Journal of Pharmaceutical and Clinical Research, 11(4), 133-137. https://doi.org/10.22159/ajpcr.2018.v11i4.23724

Babu, C. M., Chakrabarti, R., Sambasivarao, K. R. S. (2008). Enzymatic isolation of carotenoid-protein complex from shrimp head waste and its use as a source of carotenoids. LWT - Food Science and Technology, 41(2), 227-235. https://doi.org/10.1016/j.lwt.2007.03.006

Cazzonelli, C. I. (2011). Carotenoids in nature: Insights from plants and beyond. Functional Plant Biology, 38(11), 833-847. https://doi.org/10.1071/FP11192

Çinar, I. (2005). Effects of cellulase and pectinase concentrations on the colour yield of enzyme extracted plant carotenoids. Process Biochemistry, 40(2), 945 949. https://doi.org/10.1016/j.procbio.2004.02.022

Divya, P., Puthusseri, B., Neelwarne, B. (2012). Carotenoid content, its stability during drying and the antioxidant activity of commercial coriander (Coriandrum sativum L.) varieties. Food Research International, 45(1), 342-350. https://doi.org/10.1016/j.foodres.2011.09.021

Dufosse, L., Galaup, P., Yaron, A., Arad, S. M. Blanc, P. Murthy, K. N. C., Ravishankar, G. A. (2005). Microorganisms and microalgae as sources of pigments for food use: A scientific oddity or an industrial reality? Trends in Food Science \& Technology, 16(9), 389-406. https://doi.org/10.1016/j.tifs.2005.02.006 El-Zaeddia, H., Calín-Sáncheza, A., Nowickac, P., Martínez-Toméb, J., NogueraArtiagaa, L., Burlóa, F., Wojdyłoc, A., Carbonell-Barrachina, A. A. (2017) Preharvest treatments with malic, oxalic, and acetylsalicylic acids affect the phenolic composition and antioxidant capacity of coriander, dill and parsley. Food Chemistry, 226, 179-186. http://dx.doi.org/10.1016/i.foodchem.2017.01.067

FAOSTAT. (2013). Production yearbook. Food and Agriculture Organization of the United Nations: Rome, vol. 59.

Heinonen, M. I. (1990). Carotenoids and pro-vitamin A activity of carrot (Daucus carota L.) Cultivars. Journal of Agricultural and Food Chemistry, 38(3), 609-612. https://doi.org/10.1021/jf00093a005

Ivanova, A. V., Petrov, A. S., Vezhlivtsev, E. A. Matern, A. I. (2017). Method for determination of antioxidant activity using the method of electron paramagnetic resonance spectroscopy. Application for invention 2015157391 Priority date is 31.12.2015. (Decision on the grant of a patent on January 10, 2017) (In Russian).

Janve, B., Prasad, K. K., Prasad, K. (2014). Development of fiber rich functiona mango jam: studies on its formulation. Lambert Academic Publishing: Saarbrücken, 96 pp.

Koolman, J., Roehm, K. H. (2011). Color atlas of biochemistry. Thieme Verlag: Stuttgart, 504 pp. ISBN-13: 978-3131003737

Kotecha, P. M., Desai, B. B., Madhavi, D. L. (1998). Carrot. In: Handbook of vegetable science and technology: Production, composition, storage and processing. Salunke, D.K., Kadam, S.S., (Eds.); Marcel Dekker: New York, 741 pp.

Leja, M., Kamińska, I., Kramer, M., Maksylewicz-Kaul, A., Kammerer, D. Carle, R., Baranski, R. (2013). The Content of phenolic compounds and radica scavenging activity varies with carrot origin and root color. Plant Foods for Human Nutrition, 68(2), 163-170. https://doi.org/10.1007/s11130-013-0351-3

Lichtenthaler, H. K.; Buschmann, C. (2001). Chlorophylls and carotenoids: Measurement and characterization by UV-VIS spectroscopy. In: Current protocols in food analytical chemistry (CPFA), Wrolstad, R. E., Acree, T. E., An, H., Decker, E. A., Penner, M. H., Reid, D. S., Schwartz, S. J., Shoemaker, C. F., Sporns, P. (Eds.). John Wiley and Sons: New York, F4.3.1-F4.3.8. https://doi.org/10.1002/0471142913.faf0403s01

Lineback, D. R. (1999). The Chemistry of complex carbohydrates. Marcel Dekker, New York, 41 pp.

Mata-Gómez, L. C., Montañez, J. C., Méndez-Zavala, A., Aguilar, C. N. (2014)

Biotechnological production of carotenoids by yeasts: An overview. Microbial Cell Factories, 13(1), 12. https://doi.org/10.1186/1475-2859-13-12
Müller, L., Fröhlich, K., Böhm, V. (2011). Comparative antioxidant activities of carotenoids measured by ferric reducing antioxidant power (FRAP), ABTS bleaching assay $(\alpha \mathrm{TEAC}), \mathrm{DPPH}$ assay and peroxyl radical scavenging assay. Food Chemistry, 129(1), 139-148. https://doi.org/10.1016/i.foodchem.2011.04.045

Myers, R. H., Montgomery, D. C., Anderson-Cook, C. M. (2016). Response surface methodology: process and product optimization using designed experiments. Wiley: New Jersey, 856 pp. ISBN: 978-1-118-91601-8

Pfander, H. (1992). Carotenoids: An overview. Methods in Enzymology, 213, $3-$ 13. https://doi.org/10.1016/0076-6879(92)13105-7

Pradeesh, S., Swapna, T. S. (2018). Antioxidant activity in leaves of Sesbania Grandiflora (L.) Pers. Asian Journal of Pharmaceutical and Clinical Research, 11(1), 116-119. http://dx.doi.org/10.22159/ajpcr.2018.v11i1.7132

Sadighara, P., Roshanzamir, T., Jahanbakhsh, M., Bahmani, M., Abaszadeh, A., Naghdi, N., Afsordeh, O., Rafieian-Kopaei, M. (2016). Enzymatic method: The best choice for extraction of carotenoids of Alfalfa. Journal of Chemical and Pharmaceutical Science, 9(3), 1322-1324.

Saini, R. K., Keum, Y. S. (2018). Carotenoid extraction methods: A review of recent developments. Food Chemistry, 240, 90-103. https://doi.org/10.1016/j.foodchem.2017.07.099

Saini, R. K., Nile, S. H., Park, S. W. (2015). Carotenoids from fruits and vegetables: chemistry, analysis, occurrence, bioavailability and biologica activities. Food Research International, 76 (part 3), 735-750. https://doi.org/10.1016/j.foodres.2015.07.047

Sauro, H. M. (2011). Enzyme kinetics for systems biology. Ambrosius Publishing: Lexington, 319 pp. ISBN-13: 978-0982477311

Singh, A., Ahmad, S., Ahmad, A. (2015). Green extraction methods and environmental applications of carotenoids-A review. RSC Advance, 5(77), 62358-62393. https://doi.org/10.1039/C5RA10243J

Steinberg, D. M., Bursztyn, D. (1998). Noise factors, dispersion effects and robust design. Statistica Sinica, 8(1), 67-85.

Thaipong, K., Boonprakob, U., Zevallos, L. C., Byrne, D. H. (2005). Hydrophilic and lipohilic antioxidant activities of guava fruits. The Southeast Asian Journal of Tropical Medicine and Public Health, 36(4), 254-257.

Zhang, D., Hamauzu, Y. (2004). Phenolic compounds and their antioxidant properties in different tissues of carrots (Daucus carota L.). Journal of Food, Agriculture and Environment, 2, 95-100. 